\title{
The effect of progressive muscle relaxation on reducing restless legs syndrome among patients undergoing hemodialysis in a satellite/hospital unit in Indonesia
}

\author{
Tria Firza Kumala ${ }^{1}$, Linlin Lindayani ${ }^{2}$, Irma Darmawati ${ }^{2}$, Lina Safarina ${ }^{1}$ \\ ${ }^{1}$ Sekolah Tinggi Ilmu Kesehatan Jenderal Achmad Yani Cimahi. West Java. Indonesia \\ ${ }^{2}$ Sekolah Tinggi IImu Keperawatan PPNI Jawa Barat. West Java. Indonesia
}

Como citar este artículo:

Firza Kumala T, Lindayani L, Darmawati I, Safarina L. The effect of progressive muscle relaxation on reducing restless legs syndrome among patients undergoing hemodialysis in a satellite/hospital unit in Indonesia.

Enferm Nefrol. 2021 0ct-Dic;24(4):409-15.

\section{Abstract}

Introduction: Muscle relaxation is considered as an alternative therapy for restless legs syndrome (RLS).

Objective: To determine the effect of progressive muscle relaxation (PMR) on restless legs syndrome in patients undergoing hemodialysis.

Methodology: This study was conducted using the quasiexperimental design in the unit hemodialysis. The sample recruited was 12 respondents in both intervention and control group using convenience sampling. The research instrument used the International RLS Study Group Scale.

Results: The average score of RLS before and after PMR in the intervention group was 22.92 and 17.42, respectively. In the control group, the mean score of RLS before and after intervention was 24.33 and 23.50, respectively. PMR was effective to improve RLS $(p<0.005)$.

Conclusion: PMR could be an alternative to reduce RLS in patients undergoing hemodialysis. Future studies are needed to clarify the findings using more robust methods and large sample size.

\section{Correspondencia:}

Tria Firza Kumala

E-mail: tiafirza@yahoo.com
KEYWORDS: rest less legs syndrome; progressive muscle relaxation; hemodialysis.

El efecto de la relajación muscular progresiva en la reducción del síndrome de las piernas inquietas entre los pacientes sometidos a hemodiálisis en una unidad periférica en Indonesia

Introducción: La relajación muscular se considera una terapia alternativa para el síndrome de las piernas inquietas (SPI).

Objetivo: Determinar el efecto de la relajación muscular progresiva (RMP) sobre el síndrome de piernas inquietas en pacientes sometidos a hemodiálisis.

Metodología: Se llevó a cabo un estudio con diseño cuasi-experimental en la unidad de hemodiálisis. La muestra reclutada fue de 12 encuestados tanto en el grupo de intervención como en el de control, siendo el muestreo de conveniencia. El instrumento de investigación utilizado fue la Escala Internacional del Grupo de Estudio del SPI.

Resultados: En el grupo de intervención, las puntuaciones medias del SPI antes y después fueron de 22,92 y 17,42, respectivamente. En el grupo de control, las puntuaciones medias del SPI antes y después de la intervención fueron de 24,33 y 23,50, respec- 
tivamente. La RPM fue eficaz para mejorar el SPI $(p<0,005)$.

Conclusión: La RMP podría ser una alternativa para reducir el SPI en pacientes sometidos a hemodiálisis. Se necesitan estudios futuros para aclarar los hallazgos utilizando métodos más robustos y un tamaño de muestra mayor.

PALABRAS CLAVE: síndrome de piernas inquietas; relajación muscular progresiva; hemodiálisis.

\section{Introduction}

Restless Legs Syndrome (RLS) is a neurological disorder defined by a desire to move the legs due to unpleasant feelings which often occurs during long periods of inactivity $^{1-3}$. RLS pathophysiology is still obscure, and may be uremia as well as iron deficiency in its genesis ${ }^{3}$. It is considered as a peripheral disease, but studies of dopamine metabolism in the brain increase the possibility for central nervous system origin, more precisely because of the organic deficit of hypothalamic dopaminergic cells that are the source of dopamine throughout the spinal cord ${ }^{4}$.

The prevalence of RLS in patients with end-stage renal failure ranged from 25 to 50 percent, especially during hemodialysis ${ }^{5}$. Giannaki et al (2013) explained the factors that influence the severity of RLS, namely hypertension, female sex, increased body weight, length of hemodialysis, age and diabetes mellitus ${ }^{6}$. Previous studies reported that RLS could reduce quality of life, and increase sleep disorders, anxiety, depressive symptoms, and risk of cardiovascular disorders in patients undergoing hemodialysis ${ }^{3,7}$. Since the symptoms of this syndrome occur or worsen at rest and immobilization, these symptoms could improve with activity and thus moderate exercise could help to reduce the symptoms ${ }^{8}$. The guidelines suggest dopaminergic therapy (levodopa or dopamine receptor agonists: pramipexol, ropinirole, pergolide or cabergoline) as the first-line treatment for RLS in the general population; limited evidence is available on the effects of these drugs in patients with renal failure and repeated adverse effects of levodopa have been seen mainly with continuous use that restrict its usage significantly9. Therefore, an alternative intervention using non-pharmacological approach is urgently required.

Progressive muscle relaxation (PMR) is one way to improve physical work capacity and reduce functional limitations by tighten and relax some part of muscles through stimulation of the sympathetic and parasympathetic nervous system ${ }^{10}$. The relaxation technique was first introduced by Edmund Jacobson, a psychologist from Chicago who developed a physiological method against tension and anxiety ${ }^{11}$. There are several kind of relaxation methods, namely: (1) muscle relaxation, (2) diaphragmatic breathing, (3) imagery training, (4) biofeedback, and (5) hypnosis ${ }^{12}$. Progressive muscle relaxation is the cheapest method of relaxation, requires no imagination, has no side effects, is easy to do, and can make the body and mind feel calm, relaxed, and easier to sleep ${ }^{13}$. A previous study reported that progressive muscle relaxation can improve the sleep quality in patients undergoing hemodialysis ${ }^{13}$. Based on the Classification of nursing intervention (2018), strength training is a type of physical exercise that has a positive impact on patients with hemodialysis and is a form of nursing intervention ${ }^{14}$. Systematics review have been conducted to test the effectiveness of PMR on anxiety, sleep quality, and quality of life in other population ${ }^{13,15}$. However, the effect of progressive muscle relaxation on restless legs syndrome among patients with chronic renal failure undergoing hemodialysis has been less studied. The aim of this study was to test the effect of progressive muscle relaxation therapy on RLS in patients undergoing hemodialysis.

\section{Material and Method}

This study was conducted using a quasi-experimental non-equivalent control group design for four weeks.

The target population in this study were patients undergoing hemodialysis in one hemodialysis unit in Indonesia from March to October 2019. Table 1 describes the inclusion and exclusion criteria of the sample. The sampling technique used in this study is non-probability sampling with consecutive sampling approach, which is the technique of selecting samples by determining subjects who meet the research criteria included in the research within a certain period of time. The total sample used in this study were 24 respondents who were divided into the intervention group (12) and control group (12).

Sex, age, educational level, number of sessions per week, and restless legs syndrome were measured.

Restless legs syndrome (RLS) was measured before and after intervention of PMR. Control group received health education about RLS as intervention instead PMR. The procedure of PMR is described in table 2. 
Tabla 1. Inclusion and exclusion criteria of the sample.

\section{Inclusion criteria}

1. Under hemodialysis for at least 6 months.

2. Following hemodialysis weekly for $2-3$ times a week with a range of 3-4 hours each time on dialysis.

3. Have following RLS diagnostic criteria: The need to move the limbs normally associated with discomfort or uncomfortable sensations in the limbs such as pain, scratching when someone crawls on the affected part (foot or hand) and the symptoms are worse at rest (worsening in the afternoon or at night) or at least decreased movement (such as walking, rubbing feet or massaging feet).

4. Do not undergo other complementary therapies.

\section{Exclusion criteria}

1. Patients who refuse to become respondents.

2. Patients with decreased consciousness.

3. Patients with shortness of breath.

4. Patients with hemodynamic instability.

Tabla 2. Progressive muscle relaxation procedures.

\begin{tabular}{|c|c|}
\hline Steps & Things to do \\
\hline Preparation & $\begin{array}{l}\text { - Prepare environment and make sure respondents feel comfortable. } \\
\text { - Ask them to sit on a chair or lie down. } \\
\text { Instruct respondent to open or closed eye and loosen tight clothing and make sure the environment } \\
\text { around you is calm. } \\
\text { - Start by doing some deep breathing by inhale slowly and deeply through your nose and exhale throu- } \\
\text { gh your mouth (repeat several times). }\end{array}$ \\
\hline Legs muscles & $\begin{array}{l}\text { - Start by tensing the muscles in your legs with bend leg up from your ankle towards your face as high } \\
\text { as possible, but not so much that they cause pain or cramps. Hold this position for } 5 \text { to } 10 \text { seconds. } \\
\text { - Quickly release tension in your feet. Pay attention to the feelings and sensations they experience } \\
\text { when feet relax. } \\
\text { - Stay relaxed for about } 20 \text { to } 30 \text { seconds before moving to the front muscle group. }\end{array}$ \\
\hline $\begin{array}{l}\text { Buttocks } \\
\text { muscles }\end{array}$ & $\begin{array}{l}\text { - Stretch buttocks and thigh muscles. } \\
\text { - Watch how tension feels and hold this position for } 5 \text { to } 10 \text { seconds and release the tension quickly. } \\
\text { - Stay relaxed for } 20 \text { to } 30 \text { seconds. }\end{array}$ \\
\hline $\begin{array}{l}\text { Stomach } \\
\text { muscles }\end{array}$ & $\begin{array}{l}\text { - Tighten stomach muscles and focus on the tension for } 5 \text { to } 10 \text { seconds. } \\
\text { - Release the tension and relax for a count of } 20 \text { to } 30 \text {. } \\
\text { - Note the difference between how your stomach feels when tense and relaxed. }\end{array}$ \\
\hline Arms muscles & $\begin{array}{l}\text { - Make a tight fist with each hand while stretching your arms up at the wrists and focus on the sensa- } \\
\text { tions feeling when muscles are tense for a matter of } 5 \text { to } 10 \text { seconds. } \\
\text { Quickly release tension and focus on the relaxed muscles along the hands and arms for } 20 \text { to } 30 \\
\text { seconds. }\end{array}$ \\
\hline $\begin{array}{l}\text { Elbows and } \\
\text { biceps muscles }\end{array}$ & $\begin{array}{l}\text { Bend your elbows and biceps tighten as hard as you can. Hold tension for a count of } 5 \text { to } 10 \text { and quickly } \\
\text { release. Stay relaxed for } 20 \text { to } 30 \text { seconds, focusing on how the muscles feel relaxed. }\end{array}$ \\
\hline $\begin{array}{l}\text { Upper back } \\
\text { muscles }\end{array}$ & $\begin{array}{l}\text { - Tighten your upper back muscles by pulling your shoulders back as tight as possible and hold for a } \\
\text { count of } 5 \text { to } 10 \text {. } \\
\text { - Quickly release tension and relax for } 20 \text { to } 30 \text { seconds. } \\
\text { - Focus on how upper back feels now compared to when you stiffen. }\end{array}$ \\
\hline Shoulders & $\begin{array}{l}\text { - Pull shoulders up towards ears and pull them as tight as possible and hold for } 5 \text { to } 10 \text { seconds. } \\
\text { - Feel the tension in the shoulders and neck. } \\
\text { - Quickly release tension and stay relaxed for } 20 \text { to } 30 \text { seconds. }\end{array}$ \\
\hline
\end{tabular}




\begin{tabular}{|c|c|}
\hline Steps & Things to do \\
\hline $\begin{array}{l}\text { Wrinkle } \\
\text { forehead }\end{array}$ & $\begin{array}{l}\text { Wrinkle forehead up as tight as possible and hold for counts of } 5 \text { to } 10 \text { and quickly release tension } \\
\text { then stay relaxed for } 20 \text { to } 30 \text { seconds. Close eyes tightly until count } 5 \text { to } 10 \text { and focus on how the } \\
\text { tension feels. } \\
\text { Release the tension and focus on how relaxation feels to the count of } 20 \text { to } 30 \text { seconds. }\end{array}$ \\
\hline Jaw & $\begin{array}{l}\text { - Open your mouth as wide as possible and feel the tension in your jaw. } \\
\text { - Hold for } 5 \text { to } 10 \text { seconds and release. } \\
\text { - Relax your jaw - lips should be slightly open. } \\
\text { - Pay attention to the contrast between tension and relaxation. }\end{array}$ \\
\hline Final step & Continue deep breathing for several minutes. Focus on how your muscles feel relaxed. \\
\hline
\end{tabular}

Restless legs syndrome was measured using the International Restless Legs Syndrome Study Group Scale (IRLSSG) questionnaire (2003) ${ }^{16}$. The questionnaire or restless legs syndrome rating scale (RLSRS) consist of 10 questions, which included symptoms and effects on patients' feelings and lives. Each question uses a Likert scale with 5 options. Depending on their score each patient will be assigned within an interval, namely not severe (0 points), mild (1-10 points), moderate (11-20 points), severe (21-30 points) and very severe (31-40 points). A Cronbach' alpha in the current study was 0.87 .

\section{Ethical consideration}

This study has been approved by the ethical committee from affiliated university (039/III/KEPK/STIKep/ PPNI/Jabar/VII/2019). The study protocol was approved by the ethic committee of both centers and followed the Declaration of Helsinki Ethical Principles for Medical Research Involving Human Subjects. Written informed consents has been obtained prior data collection. Participants have been informed that they have right to withdraw from this study any time without any penalty. All the personal information of the studied participants was protected for its confidentiality.

\section{Analysis Data}

The results of normality test of RLS data were normally distributed both in intervention and control groups using Shapiro Wilk (pretest 0.075 and posttest 0.074, and pretest 0.092 and posttest 0.053 , respectively). Therefore, to examine different score between pre and post-test was analyzed using paired t test. The difference between intervention and control group was evaluated using independent $t$ test. We set alpha 5\% for significant level. All data were analyzed using IBM SPSS Version 22.

\section{Results}

Table 3 shows the demographic comparison between intervention and control group. The mean age of the intervention group was 56.78 ( $S D= \pm 13.34$ ) years, while the mean age of control group was 55.61 ( $S D= \pm 12.66)$ years. About half of participants were female, had education level above senior high school, and frequency of hemodialysis was twice a week. There were no significant difference between intervention and control group in terms of age, gender, education level, and frequency of hemodialysis ( $p$-value $>0.05$ ).

Tabla 3. Participant characteristics $(n=24)$.

\begin{tabular}{l|c}
\hline & $n(\%)$ \\
\hline Age $($ Mean \pm SD) & $56.18 \pm 13.00$ \\
\hline $\begin{array}{l}\text { Gender }(n, \%) \\
\text { Male }\end{array}$ & $13(54.2)$ \\
Female & $11(45.8)$ \\
\hline Education level $(n, \%)$ & \\
Below senior high school & $11(45.8)$ \\
Above senior high school & $13(54.2)$ \\
\hline Frequency of HD ( $n, \%)$ & $9(37.5)$ \\
Once a week & $15(62.5)$ \\
\hline Twice a week & \\
\hline
\end{tabular}


Table 4 shows the mean RLS score in the intervention group before receiving progressive muscle relaxation therapy was $22.92(S D= \pm 1.88)$ with the lowest score was 21 and the highest score of 27 . After receiving progressive muscle relaxation therapy (PMR), the average RLS scale was $17.42(S D= \pm 2.906)$ with the lowest scale was 13 and the highest was 22. In the control group, the average of RLS score before the intervention was 24.33 (2.146) with the lowest score was 22 and the highest scale of 28. After intervention, the average $\mathrm{RLS}$ score was $23.50(\mathrm{SD}= \pm 1.446)$, the lowest scale was 22 and the highest scale was 27 .

Tabla 4. Comparison of demographic and clinical information between intervention and control group.

\begin{tabular}{|c|c|c|c|}
\hline & $\begin{array}{l}\text { Intervention group, } \\
\qquad n=12\end{array}$ & $\begin{array}{c}\text { Control group } \\
n=12\end{array}$ & p-value \\
\hline Age $($ mean $\pm S D)$ & $56.78 \pm 13.34$ & $55.61 \pm 12.66$ & $0.146 a$ \\
\hline \multicolumn{4}{|l|}{ Gender ( $n, \%)$} \\
\hline Male & $7(58.3)$ & $6(50.0)$ & \multirow[t]{2}{*}{$0.653 b$} \\
\hline Female & $5(41.7)$ & $6(50.0)$ & \\
\hline \multicolumn{4}{|l|}{ Education level $(n, \%)$} \\
\hline Below senior high school & $6(50.0)$ & $5(41.7)$ & \multirow[t]{2}{*}{$0.284 b$} \\
\hline Above senior high school & $6(50.0)$ & $7(58.3)$ & \\
\hline \multicolumn{4}{|l|}{ Frequency of HD (n, \%) } \\
\hline Once a week & $4(33.3)$ & $5(41.7)$ & \multirow[t]{2}{*}{$0.117 b$} \\
\hline Twice a week & $8(66.7)$ & $7(58.3)$ & \\
\hline
\end{tabular}

HD: hemodialysis, SD: standard deviation.

Note: a $p$-value was resulted from independent $t$ test. b $p$-value was resulted from chi-square test.

Tabla 5. Mean RLS Scale before and after intervention ( $n=12)$.

\begin{tabular}{|c|c|c|c|}
\hline & $\begin{array}{l}\text { RLS Scale Before } \\
\text { (Mean } \pm \text { SD) }\end{array}$ & $\begin{array}{c}\text { RLS Scale After } \\
\text { (Mean } \pm \text { SD) }\end{array}$ & p value* \\
\hline $\begin{array}{l}\text { Intervention Group } \\
(n=12)\end{array}$ & $22.92 \pm 1.881$ & $17.42 \pm 2.906$ & 0.001 \\
\hline $\begin{array}{l}\text { Control Group } \\
(n=12)\end{array}$ & $24.33 \pm 2.146$ & $23.50 \pm 1.446$ & 0.001 \\
\hline
\end{tabular}

Table 5 shows a bivariate analysis result. The mean of RLS score in patients undergoing hemodialysis after intervention of progressive muscle relaxation therapy was 17.42 and the mean RLS score in the control group was 23.50. From the results of table 4 shows that the means RLS score before PMR was 22.92 while the mean RLS score PMR was 17.4, p-value $=0.001$.

\section{Discussion}

Our study found that majority of patients within the sample experienced moderate to severe RLS. The potential mechanism why patients undergoing hemodialysis could experience severe RLS might be iron deficiency affecting nervous and musculoskeletal system ${ }^{3}$. The appearance of RLS in hemodialysis patients could have negative impact such as sleep disturbance, anxiety, depressive symptoms, reduce quality of life, and increasing the risk of cardiovascular disorders ${ }^{3}$. Previous studies reported that the factors that influenced the severity of RLS were hypertension, gender, increased body weight, length of hemodialysis, age, and comorbidities such as diabetes mellitus ${ }^{6,16}$. As all of them are common in this kind of patient we think healthcare professionals need to pay more attention on taking care and monitoring of RLS in hemodialysis patients.

In the intervention groups, progressive muscle relaxation (PMR) therapy could decrease RLS. It might associate with it the levels of endorphins which have the function of regulating pain, emotions, and hormone secretion ${ }^{16}$. In fact, high levels of endorphins will make it easier for someone to receive therapy, and the other way around 17,18 . In this study, the PMR is only done twice a week on Mondays and Thursdays following the respondent's hemodialysis schedule. Progressive muscle relaxation therapy in our study was given for 4 weeks, in accordance with a review of previous studies conducted by Mousavi et al $(2016)^{19,20}$. The dose of physical exercise given to patients with chronic kidney failure is 3 times a week 1. However, in Indonesia, the frequency of hemodialysis is generally 2 times a week. Smart and Stelee (2013) recommend physical exercise for a long period of time, which is 5 months to provide great beneficial effects ${ }^{1}$.

This study showed that PMR could be an alternative approached to reduce the RLS score in patients undergoing hemodialysis. The possible mechanism by 
which PMR reduce RLS could be that respondents took therapy regularly and could follow the researcher's direction well. In this case, the researchers also appreciated the enthusiasm of the respondents to take the proven therapy in the absence of respondents who drop out. This exercise can help to relieve overall levels of tension and stress, and help when you feel anxious. It can also help to reduce physical conditions such as stomach pain or headaches, and also improve sleep. People with anxiety problems are often very tense all day long even if they don't know how relaxing it feels. By practicing PMR, respondents can learn how to distinguish between feeling tight muscles and relaxed muscles. Then, when the first sign of muscle tension accompanying feelings of anxiety, the sufferer can start introducing this relaxed state.

This study has several limitations. First, no randomization and blinded that could be potential to produce results bias on the effect of PMR on RLS. Another limitation was small sample size and only limited to one hospital in Indonesia that might affect on generalizability. Future studies can focus on tailoring the PMR technique via considering the randomization, blinding factor, and large sample size in case of the patients with different degrees of RLS.

This study describes the effect of progressive muscle relaxation (PMR) on RLS among patients undergoing hemodialysis. From the results obtained we can consider that PMR could reduce the RLS.

In this case, the nurse has an important role in helping patients to meet the comfort needs due to suffering from RLS. Nurses can serve as direct care providers to alleviate RLS symptoms as well as working with other health professionals. Nurses could teach patients to do PMR to overcome RLS and provide PMR on patients during hemodialysis process. Future studies are needed to clarify the findings using more robust methods and larger sample size.

Recepción: 23-06-20

Aceptación: 15-09-21

Publicación: 30-12-21

\section{Bibliografía}

1. Smart N, Stelee M. Exercise training in hemodialysis patients: A systematic review and meta-analysis. Nephrology. 2011;16:626-32.

2. Long A. In: Other movement disorders. 24 ed. Goldman LSA, editor. Philadelphia: Saunders Elsevier. 2011.

3. Restless Legs Syndrome Foundation. Causes diagnosis and treatment. 2018. Available from: http:// www.rls.org.

4. Clemens S, Rye D, Hochman S. Restless legs syndrome: revisiting the dopamine hypothesis from the spinal cord perspective. Neurology. 2006;67(1): 125-30.

5. Abeera M, Syed Rizwan A, B. Restless Leg Syndrome. Bookshelf ID: NBK430878 PMID: 28613628 StatPearls Publishing LLC. 2008. Available from: https://www.ncbi.nlm.nih.gov/books/NBK430878/.

6. Giannaki CD, Zigoulis $P$, Karatzaferi C. Periodic limb movements in sleep contribute to futher cardiac structure abnormalities in hemodialysis patients with restless legs syndrome. J Clin Sleep Med. 2013;9:147-53.

7. Kushida C, Martin M, Nikam P, Blaisdell B, Wallenstein $G$, Ferini- Strambi $L$, et al. Burden of restless legs syndrome on health-related quality of life. Qual Life Res. 2007;16(4):617-24.

8. Sakkas GK, Hadjigeorgiou GM, Karatzaferi C, Maridaki MD, Giannaki CD, Mertens PR, et al. Intradialytic aerobic exercise training ame- liorates symptoms of restless legs syndrome and improves functional capacity in patients on hemodialysis: a pilot study. ASAIO J. 2008;54(2):185-90.

9. Molnar MZ, Novak M, Mucsi I. Management of Restless Legs Syndrome in Patients on Dialysis. Drugs. 2006;66:607-24.

10. Luberto CM, Hall DL, Park ER, Haramati A, Cotton S. A Perspective on the Similarities and Differences Between Mindfulness and Relaxation. Glob Adv Health Med. 2020 5;9:2164956120905597. 
11. Jacobson, E. Progressive relaxation. Chicago: Chicago University Pres. 1938.

12. Miltenberger RG. Behavior Modification Principles and Procedures (4th ed.). Australia: Thompson Wadsworth. 2008.

13. Melo-Dias C, Lopes RC, Cardoso D, Bobrowicz-Campos E, Apóstolo J. Schizophrenia and Progressive Muscle Relaxation - A systematic review of effectiveness. Heliyon.2019;5(4): e01484.

14. Butcher HK, Bulechek GM, Dochterman JM, Wagner CM. Nursing Interventions Classification (NIC) (7th ed.). St. Louis: M0: Elsevier. 2018.

15. Haseena TA, Sreelekshmi J. Effect of progressive muscle relaxation on quality of sleep among patients undergoing hemodialysis. GJRA. 2015; 4(2).

16. The International Restless Legs Syndrome Study Group (Arthur S. Walters MD - Group Organizer and Correspondent), Towards a better definition of the restless legs syndrome. Mov Disord 1995;10: 634-42.
17. Manzoni GM, Pagnini F, Castelnuovo G, Molinari E. Relaxation training for anxiety: a ten-years systematic review with meta-analysis. BMC Psychiatry [Internet] 2008; 8:41. Available from: https://doi. org/10.1186/1471-244X-8-41.

18. Smeltzer, S.C \& Bare, B.G. Buku ajar Keperawatan Medikal Bedah. Jakarta: EGC. 2013.

19. Beladi-Mousavi SS, Jafarizade M, Shayanpour $S$, Bahadoram M, Moosavian SM, Houshmand G. Restless Legs Syndrome: Associated Risk Factors in Hemodialysis Patients. Nephrourol Mon. 2015 Nov 29;7(6):e31967. D0I: https://doi.org/10.5812/numonthly.31967.

20. Mousavi M, Soleimani M A, Akrami R, Tadayonfar $M$. The effect of progressive muscle relaxation on the severity of restless leg syndrome in patients under treatment with hemodialysis. Hayat. 2016. 106;

Este artículo se distribuye bajo una Licencia Creative Commons Atribución-NoComercial 4.0 Internacional. https://creativecommons.org/licenses/by-nc/4.0/ 